\title{
PENANAMAN NILAI-NILAI MORAL MELALUI KESENIAN REOG KENDANG TERHADAP PELAJAR DI KABUPATEN TULUNGAGUNG
}

\author{
Wiga Nugraheni \\ Fakultas Bahasa dan Seni, Universitas Negeri Yogyakarta \\ E-mail: wiga_nugraheni@gmail.com
}

\begin{abstract}
Abstrak
Kesenian Reog Kendang di Kabupaten Tulungagung merupakan gubahan tari rakyat sejak tahun 1978 yang menggambarkan tentang arak-arakan prajurit pasukan Kedhirilaya tatkala mengiring pengantin Ratu Kilisuci ke Gunung Kelud untuk menyaksikan hasil pekerjaan Jathasura mengenai persyaratan yang diberikannya. Kesenian tersebut dikenal oleh masyarakat Tulungagung dalam bentuk sebagai tari hiburan yang sederhana yang dibawakan oleh 6 orang penari yang menari sekaligus memainkan kendhang dhodhog. Penananam nilai-nilai moral pada seorang pelajar dapat dilakukan melalui kesenian, khususnya kesenian Reog Kendang. Kesenian ini mengajarkan anak untuk dapat melaksanakan perilaku-perilaku baik dalam kehidupan seharihari, belajar dan berlatih untuk bekerjasama, bertanggungjawab, disiplin, dan saling menghargai ketika berproses dalam menciptakan pertunjukan kesenian tersebut.
\end{abstract}

Kata kunci: nilai-nilai moral, reog, pelajar

\section{IMPLEMENTATION OF MORAL VALUES THROUGH THE ART OF THE REOG KENDANG TOWARDS STUDENTS IN TULUNGAGUNG DISTRICT}

\begin{abstract}
Reog Kendang Arts in Tulungagung Regency is a composition of folk dance since 1978 which depicts the procession of Kedhirilaya troop soldiers while accompanying the bride of Ratu Kilisuci to Mount Kelud to witness the results of Jathasura's work on the requirements given. The art is known by the Tulungagung community as a simple entertainment dance performed by 6 dancers who dance while playing kendhang dhodhog. The implementation of moral values in a student can be done through art, especially the art of Reog Kendang. This teaches children to be able to conduct good behaviors in their daily lives, learn and practise cooperating, be responsible, discipline, and respect each other when proceeding to create these artistic performances.
\end{abstract}

Keywords: moral values, reog, students

\section{PENDAHULUAN}

Keterpurukan moral bangsa yang dibarengi dengan banyaknya konflik dan kekerasan di berbagai tempat di tana air hingga sekarang tampaknya sulit diatasi. Kekerasan merupak fenomena yang nyata dari sejarah manusia, tidak bisa dihapuskan begitu saja, dan dianggap sebagai bentuk penyimpangan manusia yang bersifat sementara. Namun harapan orang agar suatu kekerasan dalam bentuk apapun segera mendapat penanganan, tetapi ingga sekarng diagnosis untuk mengantisipasi terjadinya kekerasan masih tertunda pelaksanannya belum merata ke berbagai penjuru di Indonesia.

Banyaknya kejadian konflik kekerasan di atas memperlihatkan bahwa pola pikir emosional masih mendominasi masyarakat Indonesia. Akibatnya dari hal tersebut adalah 
sulit untuk menuju keidupan yang harmonis, serasi, selaras, dan seimbang. Atas nam emosional itu orang mudah menumpahkan emosinya dalam berbagai bentuk kekerasan yang tidak bermoral dan berprilaku sosial. Oleh karena itu untuk menuju karakter bangsa yang baik serta menjauhkan perilaku kekerasan setidak-tidaknya harus diproses melalui pendidikan dan pembelajaran kepada generasi penerus bangsa yaitu para pelajar.

Nilai-nilai edukatif merupakan nilai-nilai pendidikan yang di dalamnya mencakup sikap individu dalam kehidupan pribadi, kehidupan sosial, dan kehidupan yang berhubungan dengan Tuhan. Berbagai penanaman nilai edukatif melalui pendekatan moral dilakukan dengan berbagai cara, baik formal maupun nonformal. Moral adalah ajaran tentang baik buruk yang diterima umum mengenai akhlak atau kondisi mental yang mempengaruhi seseorang menjadi tetap bersemangat, berani, disiplin dan sebagainya (Kamus Lengkap Bahasa Indonesia: 388). Sikap moral mencakup kata hati, rasa percaya diri, empati, cinta kebaikan, pengendalian diri dan kerendahan hati. Perilaku moral mencakup kemampuan, kemauan dan kebiasaan. Dapat disimpulkan bahwa pengertian moral/moralitas adalah suatu tuntutan perilaku yang baik yang dimiliki individu sebagai moralitas, yang tercermin dalam pemkiran/konsep, sikap, dan tingkah laku. Pembelajaran di sini merupakan proses usaha yang dilakukan untuk memperoleh perubahan tingkah laku sebagai hasil belajar (Jazuli, 2008: 137). Pengertian tari menurut Kamus Besar Bahasa Indonesia adalah gerakan badan (tangan dan sebagainya) yang berirama dan biasanya diiringi bunyi-bunyian (musik, gamelan, dan sebagainya). Sehingga dapat diselaraskan bahwa pembelajaran tari merupakan suatu proses kreatif dan apresiatif melalui kegiatan meniru guna mengembangkan kepribadian anak yang positif dalam menciptakan kedewasaan.

Kesenian adalah bagian dari kebudayaan yang berkaitan erat dengan kehidupan manusia. Di dalam berkehidupan tersebut manusia mempunyai tata aturan yang biasa disebut dengan adat istiadat yang menciptakan berbagai jenis kebudayaan yang akan menjadi sebuah ciri khas masyarakat di daerah tersebut. Kesinian tumbuh dan berkembang di masyarakat seiring dengan perkembangan sosial budaya masyarakat pendukungnya.

Dari berbagai macam bentuk kesenian, salah satunya adalah seni tari yang menunjukkan keindahan gerak-gerak anggota badan manusia yang berirama dan berjiwa. Seni tari mempunyai banyak keberagaman jenis kesenianya salah satu diantaranya adalah Kesian kerakyatan.

Dalam hubungan itu posisi kesenian kerakyatan daerah khusunya tari Reog Kendang dari Tulungagung Jawa Timur menjadi sering disebut sebagai wadah pembelajaran nilai edukatif dalam menuju pembentukan bangsa yang bermoral. Menjurut cerita konon katanta reog kendang ini adalah kisah prajurit Kedirilaya yang arak-arakan mengiring Ratu Kilisuci ke Gunung Kelud, yang diwakili oleh enam penari. Memang leluhur kita, selalu mengaitkan antara peristiwa dengan wujud kesenian, salah satunya Reog Kendang ini. Menurut cerita yang dituturkan oleh Bapak Endin, Beliau seorang penggerak kesenian dan kebudayaan di Tulungagung.

Dalam Kesenian Tari Reog Kendang nilai-nilai yang terdapat dalam tarian ini mencerminkan sifat kearifan lokal kesenian tradisional. Kesenian sendiri, bersangkutan mengenai proses pembelajaran dari lingkungan untuk manusia. Dari sebuah pengamatan sosial, pola prilaku kehidupan, maupun wacana yang sedang hangat dibicarakan, bisa diproses melalui kesenian, sehingga dari kesenian pulalah kita bisa mengambil sikap dalam menyikapi permasalahan. Belajar kesenian tidak hanya sekedar mempelajari praktik atau tekniknya melainkan berbagai macam aspek nilai estetika dan etika yang menjadi poros budaya dalam berkesenian. Poros budaya itu menunjang kelengkapan nilai kehidupan manusia atau nilai moral.

Lembaga pendidikan baik formal maupun nonformal memiliki tugas mempersiapkan terbentuknya generasi penerus bangsa yang 
berakhlak mulia dan bermoral yang diwarnai dengan semangat pelestarian kesenian budaya daerah untuk pengembangan potensi diri dan memanfaatkannya untuk mencapai kebahagiaan lahir dan batin. Oleh karena itu dalam tulisan ini diketahui tujuan penulisan antara lain: (1) Untuk mengetahui apa saja nilai moral yang ada dalam Kesenian Reog Kendang di Kabupaten Tulungagung, (2) Untuk mengetahui sejarah Kesenian Reog Kendang di Kabupaten Tulungagung, dan (3) Untuk mengetahui bentuk penyajian Kesenian Reog Kendang di Kabupaten Tulungagung.

\section{PEMBAHASAN}

\section{Nilai Moral}

Nilai-nilai moral merupakan nilai edukatif yaitu nilai-nilai pendidikan yang di dalamnya mencakup sikap individu dalam kehidupan pribadi, kehidupan sosial, dan kehidupan yang berhubungan dengan Tuhan. Berbagai penanaman nilai edukatif melalui pendekatan moral dilakukan dengan berbagai cara, baik formal maupun nonformal. Moral adalah ajaran tentang baik buruk yang diterima umum mengenai akhlak atau kondisi mental yang mempengaruhi seseorang menjadi tetap bersemangat, berani, disiplin dan sebagainya (Kamus Lengkap Bahasa Indonesia: 388). Sikap moral mencakup kata hati, rasa percaya diri, empati, cinta kebaikan, pengendalian diri dan kerendahan hati. Perilaku moral mencakup kemampuan, kemauan dan kebiasaan. Dapat disimpulkan bahwa pengertian moral/ moralitas adalah suatu tuntutan perilaku yang baik yang dimiliki individu sebagai moralitas, yang tercermin dalam pemkiran/konsep, sikap, dan tingkah laku. Pembelajaran di sini merupakan proses usaha yang dilakukan untuk memperoleh perubahan tingkah laku sebagai hasil belajar (Jazuli, 2008: 137). Pengertian tari menurut Kamus Besar Bahasa Indonesia adalah gerakan badan (tangan dan sebagainya) yang berirama dan biasanya diiringi bunyibunyian (musik, gamelan, dan sebagainya). Sehingga dapat diselaraskan bahwa pembelajaran tari merupakan suatu proses kreatif dan apresiatif melalui kegiatan meniru guna mengembangkan kepribadian anak yang positif dalam menciptakan kedewasaan.

Penanaman nilai moral pada dasarnya merupakan suatu proses awal yang dilakukan oleh orang tua untuk memberikan bimbingan, perhatian, dan pemberian contoh-contoh melalui tindakan yang bersifat positif kepada anak. Bentuk dari penanaman nilai moral dalam suatu keluarga yang pada umumnya dilakukan oleh orang tua, antara lain: pemberian bimbingan budi pekerti, nilai agama dan sosial. Nilai moral ini akan dapat diamati pada anak melalui perilaku maupun nilai sosialnya, yang dapat diamati melalui pergaulan anak di sekolah maupun masyarakat. Mengingat bahwa penanaman nilai moral adalah proses, maka hal ini dapat diberikan melalui sekolah atau lembaga pendidikan yang direncanakan dan dirancang secara matang. Nilai-nilai moral tersebut antara lain: beriman, disiplin, bersemangat, bertanggung jawab, jujur, kreatif, percaya diri, sopan santun, sabar, sikap hormat, rasa indah, rasa malu, menghargai sesama, mandiri, rajin, ikhlas, ramah tamah, dan rasa kasih sayang. Segenap unsur-unsur sosial dan budaya terdapat dua unsur yang terpenting yaitu kerangka aspirasi-aspirasi dan unsurunsur yang mengatur kegiatan-kegiatan untuk mencapai aspirasi-aspirasi tersebut. Dengan kata lain, ada nilai sosial budaya yang merupakan rangkaian dari konsep-konsep abstrak yang hidup di dalam alam pikiran bagian terbesar dari warga masyarakat mengenai apa yang baik dan apa yang buruk dari norma-norma yang mengatur kegiatan manusia untuk mencapai tujuan tersebut. Nilai-nilai sosial budaya tadi berfungsi sebagai pedoman dan pendorong perilku individu di dalam hidupnya. (Robert K. Merton dalam Fernandez, 1990). Pendidikan sen dapat dijadikan dasar pendidikan, karena untuk membentuk suatu kepribadian yang baik dilakukan melalui pendidikan seni (Hartono, 2007).

Upaya agar anak dapat mengenali nilai moral tidak cukup hanya dengan membaca atau diberi penjelasan, tetapi mereka juga dimungkinkan untuk dapat berpartisipasi dengan cara berperan aktif untuk merasakan 
secara fisikal atau empatinya. Dengan demikian, Keenian Reyog Kendang ini mengajarkan anak untuk mengenali dan mengetahui nilai moral pada kehidupan.

\section{Kesenian Reyog Kendang}

Asal usul cerita Reyog Kendang Tulungagung ini konon katanya adalah kisah prajurit Kedirilaya yang arak-arakan mengiring Ratu Kilisuci ke Gunung Kelud, yang diwakili oleh enam penari. Yang ingin dikisahkan dalam tarian tersebut ialah, betapa sulit perjalanan yang harus mereka tempuh, betapa berat beban perbekalan yang mereka bawa, sampai terbungkuk-bungkuk, terseok-seok, menuruni lembah-lembah yang curam, menaiki gunung yang terjal. Sesampai di puncak gunung, bagaimana mereka mengelilingi kawah melongok-longok ke dalam, dan sang putri jatuh masuk kawah, disusul kemudian prajurit melempari batu dan tanah yang mengeruk kawah tersebut, hal tersebut membuat Jathasura ingin terjun menolong sang putri juga malah ikut tewas terkubur dalam kawah, akhirnya kegembiraan dan kemenangan yang prajurit dapatkan.

Semua adegan itu mereka lakukan melalui simbol-simbol gerak tari yang ekspresif mempesona, yang banyak menggunakan langkah-langkah kaki yang serempak dalam berbagai variasi, gerakan-gerakan lambung badan, pundak, leher dan kepala, disertai mimik mukayangserius, sedangkedua tangannya sibuk mengerjakan dhodhog yang mereka gendong dengan mengikatnya dengan kain selendang yang menyilang melalui pundak kanan. Tangan kiri menahan dhodhog tersebut memberi irama yang dikehendaki, meningkahi gerak tari dalam tempo kadang cepat kadang lambat. Demikan kaya simbol-simbol yang mereka ungkapkan lewat tari mereka yang penuh dengan ragam variasi, dalam iringan gamelan yang monoton magis, dengan lengkingan selompretnya yang membawakan melodi terus-menerus tanpa putus, benar-benar memukau penonton seakanakan berada di bawah hipnotis.

\section{Penanaman Nilai Moral}

Pelajar adalah orang-orang yang ikut serta dalam proses belajar. Dan belajar itu merupakan kegiatan mengumpulkan dan menambah sejumlah ilmu dan pengetahuan, sedangkan pelajar adalah pelakunya. Dalam dunia pendidikan bisa kita lihat bahwa setiap upaya yang sengaja diciptakan agar terjadi suatu kegiatan yang edukatif antara peserta didik (pelajar) dan pendidik (pengajar). Pelajar pada dasarnya adalah konsumen dari jasa yang diberikan oleh pengajar. Pelajar merupakan aset yang penting bagi suatu negara. Karena generasi pelajar adalah bibit-bibit yang harus dikembangkan untuk menjadi generasi yang dapat memajukan agama, nusa dan bangsa. Tak hanya itu, dengan adanya pelajar maka pergaulan sosial juga semakin baik. Seorang pelajar yang baik seharusnya mampu menempatkan diri dengan baik pula di kalangan masyarakat. Karena sebagai seorang peserta didik, secara tidak langsung pengetahuan dan keterampilan yang dimiliki juga lebih baik dibandingkan yang lain. Hal ini menuntut agar pelajar berperilaku sopan agar dapat ditiru oleh masyarakat lain yang tidak berpendidikan atau berpendidikan rendah.

Menurut UU Sistem Pendidikan Nasional No 20 tahun 2003 pendidikan adalah usaha sadar dan terencana untuk mewujudkan suasana belajar dan proses pembelajaran agar peserta didik secara aktif mengembangkan potensi dirinya untuk memiliki kekuatan spiritual keagamaaan, pengendalian diri, kepribadian, kecerdasan, akhlak mulia, serta keterampilan yang diperlukan dirinya, masyarakat, bangsa, dan negara. Sedangkan moral merupakan kondisi pikiran, perasaan, ucapan, dan perilaku manusia yang terkait dengan nilai-nilai baik dan buruk. Moral secara ekplisit adalah hal-hal yang berhubungan dengan proses sosialisasi individu, tanpa moral manusia tidak bisa melakukan proses sosialisasi. Moral adalah nilai keabsolutan dalam kehidupan bermasyarakat secara utuh. Penilaian terhadap moral diukur dari kebudayaan masyarakat setempat. Moral adalah perbuatan/tingkah laku/ ucapan seseorang dalam berinteraksi dengan 
manusia. Apabila yang dilakukan seseorang itu sesuai dengan nilai rasa yang berlaku di masyarakat tersebut dan dapat diterima serta menyenangkan lingkungan masyarakatnya, maka orang itu dinilai memiliki moral yang baik, begitu juga sebaliknya. Moral adalah produk dari budaya dan agama. Setiap budaya memiliki standar moral yang berbeda-beda sesuai dengan sistem nilai yang berlaku dan telah terbangun sejak lama. Moral juga dapat diartikan sebagai sikap, perilaku, tindakan, kelakuan yang dilakukan seseorang pada saat mencoba melakukan sesuatu berdasarkan pengalaman, tafsiran, suara hati, serta nasihat, dll. Maka dapat disimpulkan bahwa pengertian pendidikan moral adalah usaha yang dilakukan secara terencana untuk mengubah sikap, perilaku, tindakan, kelakuan yang dilakukan peserta didik agar mampu berinteraksi dengan lingkungan masyarakatnya sesuai dengan nilai moral dan kebudayaan masyarakat setempat.

Berdasarkan kajian teoritis maupun empiris karakteristik anak/pelajar ditinjau dari bfaktor-faktor budayanya di mana budaya diartikan sebagai bentuk prestasi psikologis, yakni sebagai kompleks gagasan yang bersifat abstrak dan subyektif. Diperlukan sekali oleh para guru dan ilmuwan pembelajaran dalam pengembangan teori dan prinsip strategi pembelajaran moral bagi anakanak. Pembelajaran untuk mengembangkan pemahaman atau penalaran moral lebih kepada upaya perkembangan unsur kognitif yang telah ada pada diri seorang anak. Guru atau orang tua tidak dapat memaksakan nila-nilai kepada anak. Anak atau pelajar yang aktif akan mengkontruksi pengetahuan dan sistem nilai yang dipahaminya melalui pembelajaran yang ia dapatkan. Melalui sebuah interaksi sosisal budaya yang ada di masyarakat, anak akan dengan mudah bagaimana cara pemahaman moral yang baik. Yang berperan penting di sini adalah kesenian kerakyatan yang ada di masyarakat yang mampu mentransfer dan mengkontruksi nilai-nilai moral yang ada dalam kehidupan. Dengan anak atau pelajar mempelajari kesenian Reog Kendang yang di dalamnya menyimpan makna nilai moral kehidupan, maka guru atau orang tua dapat memberikan pembelajaran kesenian itu melalui sebuah organisasi atau lembaga pendidikan. Sehingga peran pendidikan moral di sini sangat penting untuk menciptakan generasi penerus bangsa yang unggul dan bermoral.

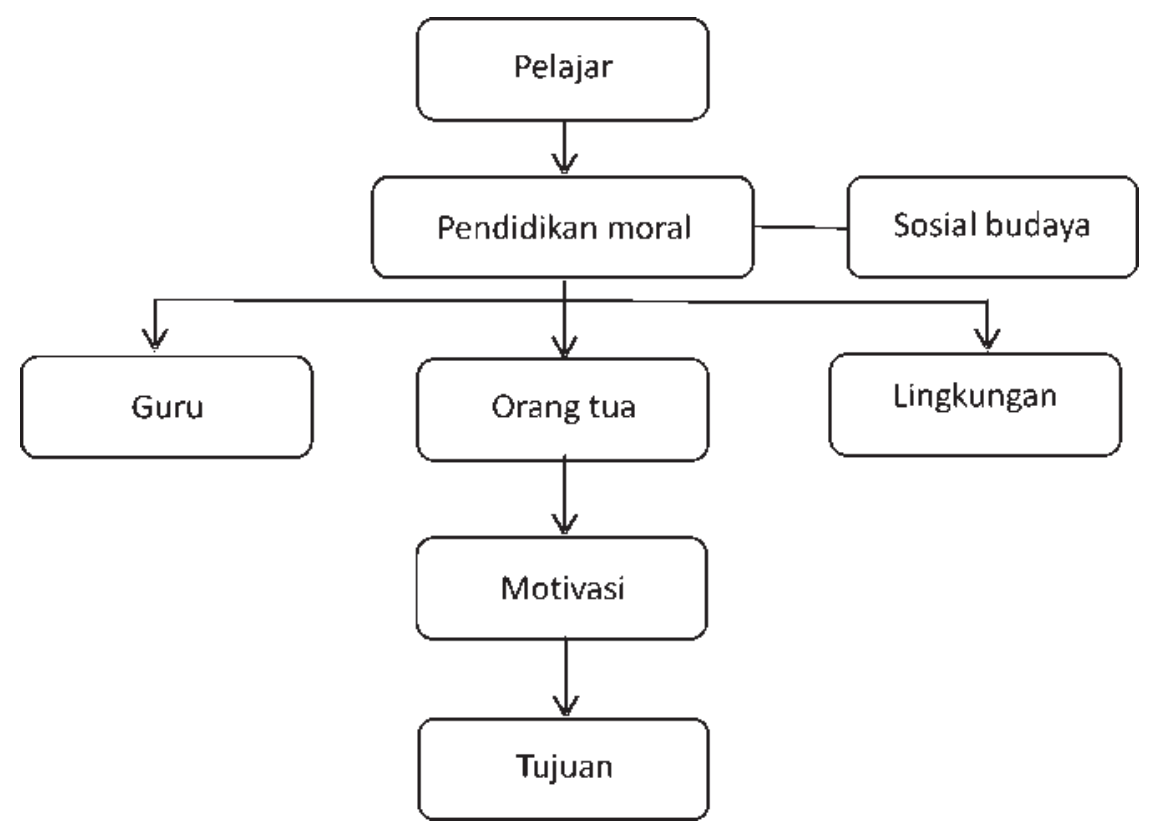

Gambar 1. Kerangka Berfikir 
Dari bagan kerangka dapat dilihat bahwa seorang pelajar itu mendapatkan sebuah pendidikan moral bisa melalui sosial budaya. Sosial budaya di sini dapat diperoleh melalui lingkungan sekitar tempat tinggal. Sosial budaya ini khususnya adalah kesenian daerah yang ada di masyarakat seperti halnya kesenian Reog Kendang ini adalah kesenian rakyat yang berkembang dan mempunyai nilai-nilai moral yang baik yang dapat digunakan sebagai motivasi dalam kehidupan.

Ketika seorang pelajar mengikuti atau berpartisipasi dalam kesenian tersebut dia dapat mengambil dan tahu nilai moral yang dapat dia peroleh. Berawal dari mengikuti sebuah proses sebagai pemain atau penari Reog Kendang, di situ dia akan bekerjasama dengan sekelompok penari, melakukan latihan bersama untuk membuat sajian tampilan yang baik untuk dipertunjukkan. Setiap anak di situ harus mampu bersosialisasi, bekerjasama dan bertanggung jawab atas permain masingmasing yang disatukan. Setiap penari menabuh atau memukul kendang dhodhog yang masingmasing berbeda cara memainkannya, sehingga setiap anak di ditu harus bertanggungjawab atas alat yang dibawa masing-masing, harus mampu berlatih dengan disiplin untuk menciptakan kelompok pertunjukan kesenian Reyog Kendang yang bagus. Ketika seorang anak di situ mampu melakukan dan mengikuti proses tersebut maka dapat dilihat disitu nilainilai moral yang dipetik dan diambil untuk diterapkan dalam kehidupan sehari-harinya. Anak mampu bekerjasama, bertanggungjwab, disiplin, dan saling menghargai satu sama lain antar penari dalam satu kelompok kesenian Reyog Kendang tersebut. Tanpa adanya sikap-sikap yang baik itu sebuah pertunjukan kesenian tidak mampu diciptakan dengan baik dan tidak dapat dinikmati keindahannya. Sehingga penanaman nilai-nilai moral tidak hanya diperoleh melalui keluarga dan pendidikan formal saja, namun melalui sebuah sosial budaya yaitu sebuah kesenian rakyat seorang anak dapat menanamkan nilai-nilai moral tersebut.

\section{Sejarah Kesenian Reog Kendang}

Asal usul cerita Reog Kendang Tulungagung ini konon katanya pada tahun 1978 adalah kisah dari prajurit Kedirilaya yang arakarakan mengiring Ratu Kilisuci ke Gunung Kelud, yang diwakili oleh enam prajurit. Yang ingin dikisahkan dalam tarian tersebut ialah, betapa sulit perjalanan yang harus mereka tempuh, betapa berat beban perbekalan yang mereka bawa, sampai terbungkuk-bungkuk, terseok-seok, menuruni lembah-lembah yang curam, menaiki gunung yang terjal. Sesampai di puncak gunung, bagaimana mereka mengelilingi kawah melongok-longok ke dalam, dan sang putri jatuh masuk kawah, disusul kemudian prajurit melempari batu dan tanah yang mengeruk kawah tersebut, hal tersebut membuat Jathasura ingin terjun menolong sang putri juga malah ikut tewas terkubur dalam kawah, akhirnya kegembiraan dan kemenangan yang prajurit dapatkan.

Semua adegan itu mereka lakukan melalui simbol-simbol gerak tari yang ekspresif mempesona, yang banyak menggunakan langkah-langkah kaki yang serempak dalam berbagai variasi, gerakan-gerakan lambung badan, pundak, leher dan kepala, disertai mimik muka yang serius, sedangkeduatangannyasibuk mengerjakan dhodhog yang mereka gendong dengan mengikatnya dengan kain selendang yang menyilang melalui pundak kanan. Tangan kiri menahan dhodhog tersebut memberi irama yang dikehendaki, meningkahi gerak tari dalam tempo kadang cepat kadang lambat. Demikan kaya simbol-simbol yang mereka ungkapkan lewat tari mereka yang penuh dengan ragam variasi, dalam iringan gamelan yang monoton magis, dengan lengkingan selompretnya yang membawakan melodi terus-menerus tanpa putus, benar-benar memukau penonton seakanakan berada di bawah hipnotis.

Secara fisik (corak) maupun karakternya Reog Kendang Tulungagung ini tidak ada kaitannya sama sekali dengan Reog Ponorogo. Lebih jelas lagi kalau kita perhatikan tiadanya kesamaan sama sekali dalam penciptaan kedua jenis kesenian rakyat tersebut. Lairnya Reog Ponorogo sama sekali tidak didasarkan pada 
motif dalam penciptaan kedua jenis kesenian rakyat tersebut. Reog Kendang Tulungagung adala benar-benar diciptaan komposisi tari, kalaupun terdapat unsur-unsuryang seolah-olah mengaitkan yang satu dengan yang lain, maka unsur-unsur itulah yang keduanya memang menggunakan nama yang sama "reyog" dan tema yang sama pula, panji/keprajuritan.

Tentang nama reyog dapat kita kembalikan kepada arti yang sebenarnya, yaitu kata sinonim atau nama jenis lain dari "kendang" atau "dhodhong". Baik Reyog Ponorogo maupun Reyog Tulungagung menggunakan alat kendang atau dhodhog atau reyog sebagai unsur musik pengiringnya yang pokok. Sebenarnya tulisan kata yang terdahulu adalah "Reyog" namun berjalan seiring waktu lidah orang jawa itu cara membacanya reyog makin pudar, huruf y makin lebur di dalamnya sehingga populernya sampai sekarang menjadi "Reog".

\section{Bentuk Penyajian}

Dalam pertunjukannya, Reog Kendang ini ditampilkan secara berkelompok oleh 6 orang penari yang masing-masing dari mereka membawa kendang atau dhodhog. Setiap kendang yang di bawa masing-masing penari memiliki jenis yang berbeda diantaranya seperti kendang kerep, kendang arang, kendang imbal 1, kendang imbal 2, kendang keplak, dan kendang trinthing. Pada pemukulan kendangnya terdiri atas tiga macam, ada yang di pukul dengan telapak tangan penuh untuk kendang kerep, imbal 1 dan keplak. Sedangkan untuk kendang arang dan imbal 2 dipukul dengan tangan bagian ujung. Yang paling berbeda pada kendang trintiing dipukul dengan alat pukul yang bernama trunthung.

Dalam pertunjukan Reog Kendang tersebut penari menari dengan energik sambil memainkan kendang mereka seirama dengan musik pengiring dan nyanyian lagu jawa. Alat musik yang digunakan oleh pengiring tersebut diantaranya adalah kenong, gong dan terompet. Kenong dan gong yang dipakai menggunakan instrument nada 5 slendro. Lagu-lagu pengiringnya dipilh yang populer dikalangan masyarakat, misalnya Gandariya, Angkleng,
Loro-loro, Pring-Padapring, Ijo-ijo, dan lain sebagainya. Irama yang digunakan dalam iringannya ada berbagai macam, ada irama lambat, irama sedang, dan irama drumbenan.

Dengan satu unit barisan penari yang berjumlah 6 orang dapat mengadakan gerakan dalam bentuk konfigurasi atau gerak lantai. Untuk gerak lantai tergantung koreografer yang sudah disepakati bersama. Namun di samping bebas dalam gerak lantai, maka perlu memperhatikan jenis-jenis gerak tari yang tetap atau baku dengan bertumpu pada gerak kepala dan kaki. Diantara gerak tari tersebut sebagai berikut :

1. Gerak baris: yaitu gerakan lurus seperti layaknya berbaris dengan dhodhog kerep berada paling depan, kaki berjalan mengikuti irama kendang, biasanya menggunakan irma drumband. Irama dan gerak ini dilakukan pada saat keluar dan masuk arena pertunjukan.

2. Gerak Sundangan: yaitu gerakan pada bahu dan kepala dengan badan agak membengkok, gerakan yang menyerupai seekor sapi atau kerbau yang sendang menyundang.

3. Gerak andul: yaitu gerakan yang mengayun-ayunkan kaki kanan ke depan dan ke belakang.

4. Gerak menthokan: yaitu gerakan berjalan sambil jongkok menirukan gaya menthok berjalan dengan pinggul digoyanggoyang.

5. Gerak gejoh bumi: yaitu gerakan dengan posisi badan agak membungkuk kaki kanan di depan menampak datar, sedangkan kaki kiri di belakang dengan mengangkat tumit sambil digejoh-gejokan ke tanah.

6. Gerak ngongak sumur: yaitu gerakan kaki kanan ke depan dan ke belakang pada saat kaki kanan ke depan pandangan ke bawah dan pada waktu kaki kanan ke belakang pandangan mata ke depan, begitu berulangulang.

7. Gerak midak kecik: yaitu jalan mundur dengan ujnung kaki menampak lebih dulu kemudian baru tumitnya mengikuti. 
8. Gerak lilingan: yaitu gerak ngliling secara berpasangan dilakukan ngliling maju berpapasan ngliling lagi begitu seterusnya.

9. Gerak kejang: yaitu grak berjalan dengan tumit diangkat, posisi badan kaku seperti orang yang sedang kejang atau seperti robot.

Demikian tadi merupakan gerak baku dalam Reog Kendang ini, sedangkan lama hitungan dari setiap gerakannya dihitung sebanyak delapan gongan. Untuk pergantian gerak akan diberi aba-aba oleh pengendang dhodhog kerep. Begitu seterusnya, kecuali karena menyesuaikan dengan gerak lantai atau membentuk konfigurasi lamanya menyesuaikan dengan kebutuhan.

Untuk kostum yang digunakan para penari merupakan kostum khusus untuk Reog Kendang yang menggambarkan para prajurit pada jaman dahulu. Pada pertunjukannya, penari menggunakan baju lengan panjang dengan kain penutup dada dengan motif berwarna kuning. Pada bagian bawah menggunakan celana sepanjang dengkul dengan beberapa attribute seperti stagen, kain batik, dan sampur berwarna. Lalu pada bagian kepala menggunakan ikat kepala, sumping dan iker yang melingkari kepala. Pada bagian kaki menggunakan kaus kaki dan klinthing. Selain itu beberapa aksesoris seperti keris, gelang tangan dan tidak lupa kendang yang ikat menggunakan sampur. Dalam perkembangannya, walaupun tergolong kesenian lama namun Reog Kendang masih tetap dilestarikan dan dijaga keberadaanya. Reog Kendang ini masih sering di tampilkan dalam acara-acara besar yang diadakan di kabupaten Tulungagung, Jawa Timur. Selain itu tarian ini juga sering di berbagai festival budaya, baik di daerah maupun tingkat nasional. Seiring dengan perkembangan jaman tarian ini mulai terlihat banyak perubahannya, dengan penambahan berbagai variasi dari segi gerakan, kostum, musik pengiring atau penyajiannya. Hal ini banyak dilakukan agar terlihat lebih menarik, namun tidak meninggalkan bentuk aslinya.

\section{KESIMPULAN}

Kesenian Reog Kendang di Kabupaten Tulungagung merupakan gubahan tari rakyat sejak tahun 1978 yang menggambarkan tentang arak-arakan prajurit pasukan Kedhirilaya tatkala mengiring pengantin Ratu Kilisuci ke Gunung Kelud untuk menyaksikan hasil pekerjaan Jathasura mengenai persyaratan yang diberikannya. Kesenian tersebut dikenal oleh masyarakat Tulungagung dalam bentuk sebagai tari hiburan yang sederhana yang dibawakan oleh 6 orang penari yang menari sekaligus memainkan kendhang dhodhog.

Di dalam pendidikan formal maupun non formal kesenian reog kendang ini mampu memberikan nilai-nilai moral yang postif kepada pelajar yang mengikuti dan berpatisipasi dalam proses pertunjukkan kesenian tersebut. Nilai-nilai moral itu antara lain seperti mampu bekerjasama dalam kelompok sosial, bertanggungjawab, disiplin dan saling menghargai antara satu dengan yang lain dalam kelompok pemain kesenian tersebut.

\section{DAFTAR PUSTAKA}

Budiningsih, Asri. 2004. Pembelajaran Moral. Jakarta: PT. Rineka Cipta.

Koentjaraningrat. 1969. Rintangan-rintangan Mental dalam Pembangunan Ekonomi di Indonesia. Jakarta. Lembaga Riset Kebnas Seri no. 2.

Dinas Kebudayaan Pariwisata Pemuda dan Olahraga Kabupaten Tulungagung. 2008. Reyog Tulungagung Kesenian Tradisional Khas. Tulungagung: Bidang Kebuyaan.

Endin, dkk. 2009. Asal-usul Reyog Tulungagung. Tulungagung: Paguyuban Jaranan dan Reyog Tulungagung.

Soedarsono.1999. Perkembangan Seni Tradisi. Yogyakarta: Ikalasti.

Koentjaraningrat. 1990. Kesenian Tradisional. Jakarta: Surya Pena.

Peursen, van. 2000. Perkembangan Kebudayaan. Jakarta: Buana Ilmu Populer.

Humardini. 2005. Perkembangan Seni Pertunjukan. Jakarta: Balai Pustaka. 
Hidajat, Robby. 2013. Kreativitas Koreografi. Malang-Jawa Timur. Surya Pena Gemilang Publishing.

Purwodarminto. 1985. Kamus Besar Bahasa Indonesia. Jakarta: Balai Pustaka.

Smith, Jacqueline. 1985. Komposisi Tari Sebuah Petunjuk Praktis Bagi Guru. Yogyakarta: Ikalasti Yogyakarta.
Sutiyono. 2009. Puspawarna Seni Tradisi dalam Perubahan Sosial Budaya. Yogyakarta: Kanwa Publiser.

Sutiyono. 2012. Paradigma Pendidikan Seni di Indonesia. Yogyakarta: UNY Press.

Sutiyono. 2012. Seni Rakyat dalam Dimensi Industrial. Imaji: Jurnal Seni dan Pendidikan Seni, Vol 10, No. 2, pp., 139161.

\section{LAMPIRAN}
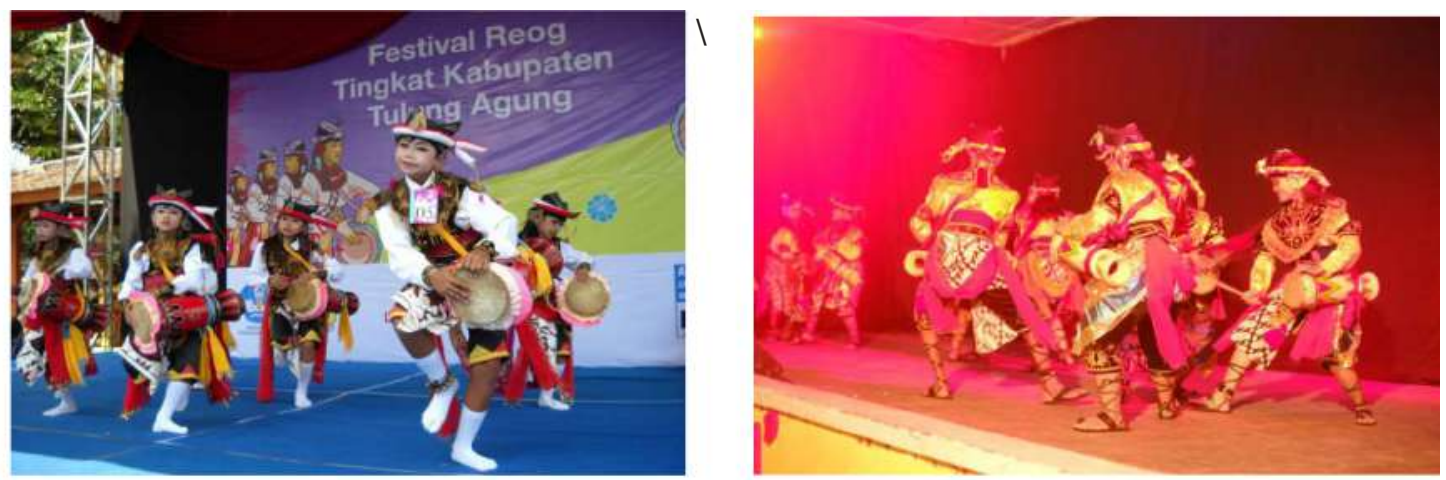

Gambar 1. Pertunjukan reog kendang oleh pelajar di Tulungagung (Dok.Wiga 2018)
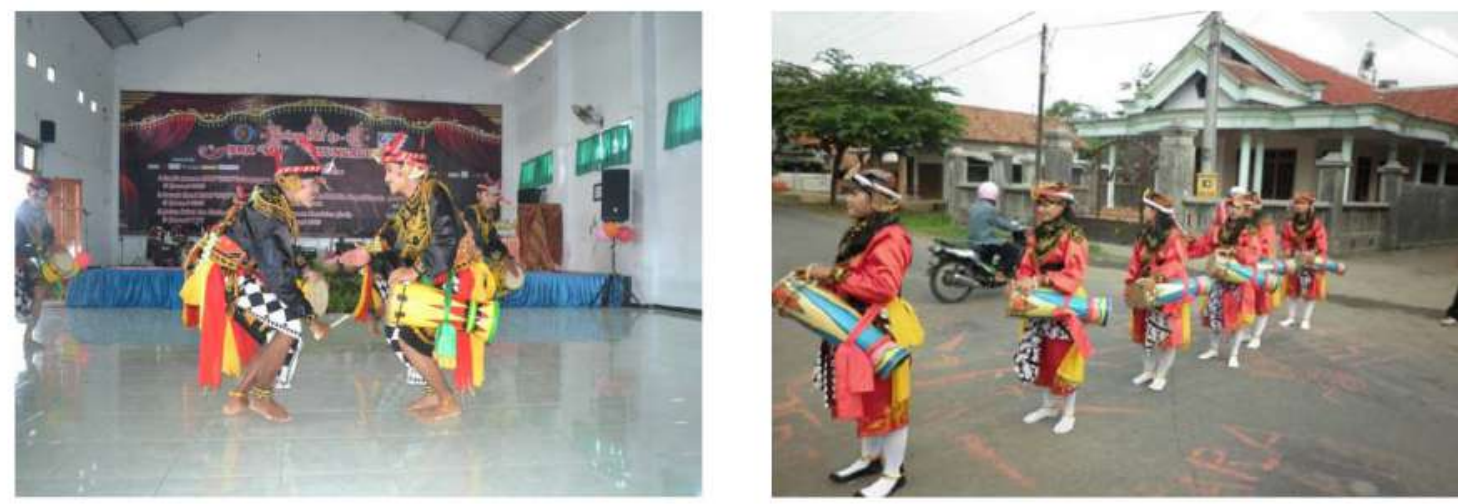

Gambar 2. Pertunjukan reog kendang oleh pelajar di Tulungagung (Dok.Wiga 2018)
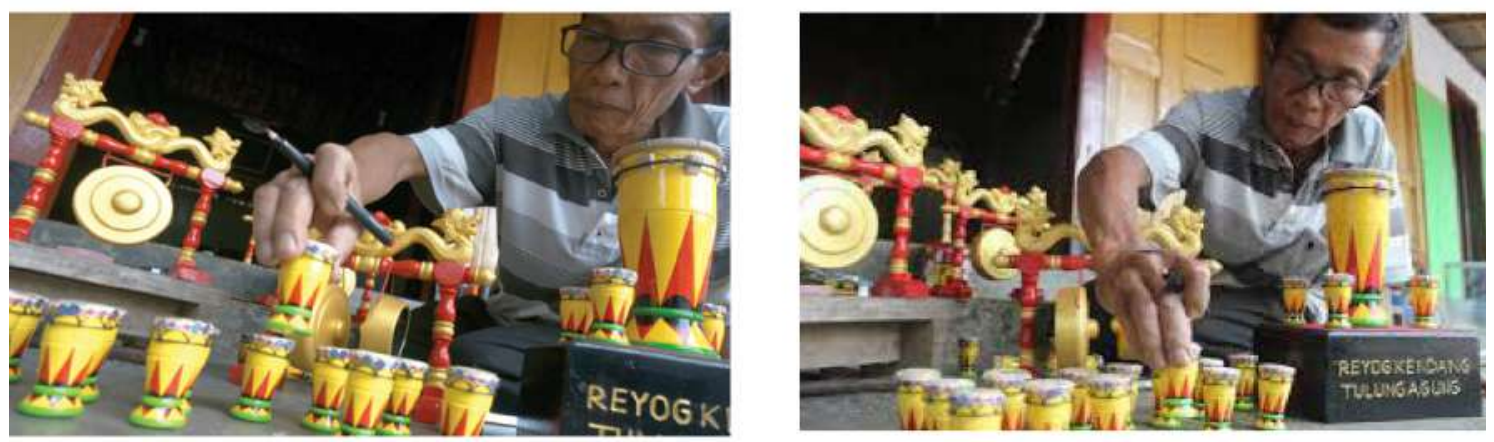

Foto di Kediaman Bapak Endin yang menunjukan miniatur Kendang Dhodhog Karyanya 


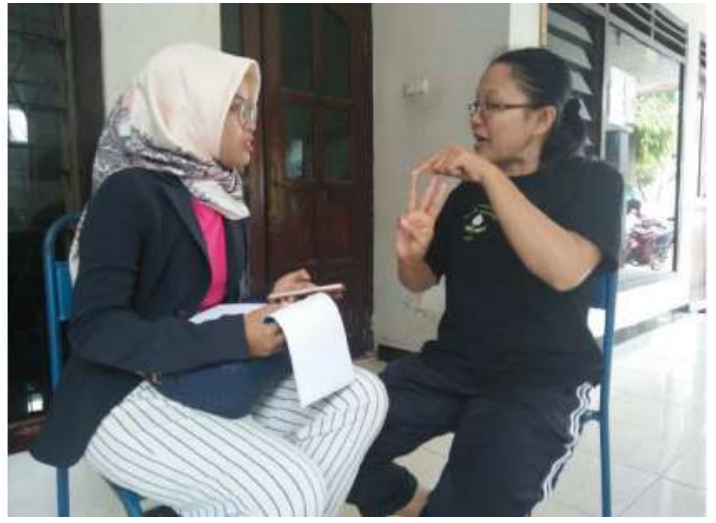

Foto Wawancara Kepada Narasumber anggota Seniman Reyog

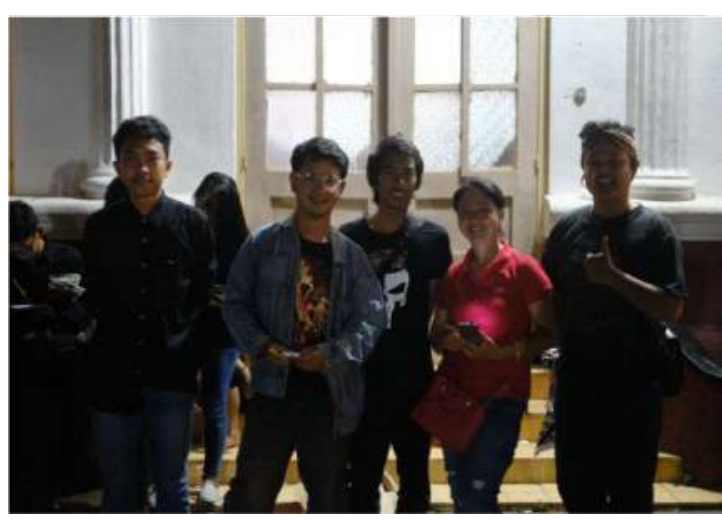

Foto bersama Narasumber dan Para Pemain Reyog Kendang

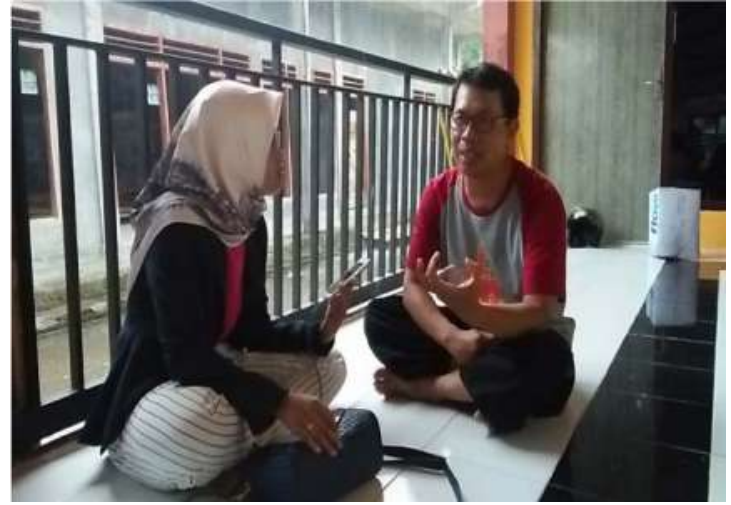

Foto Wawancara Kepada Narasumber Bapak Maskur Sanggar Gatra Kencana

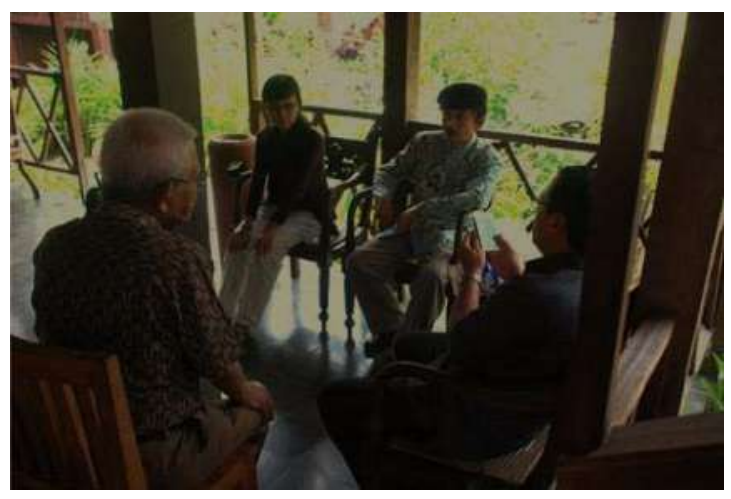

Foto bersama dengan Narasumber Bapak Untung Mulyono

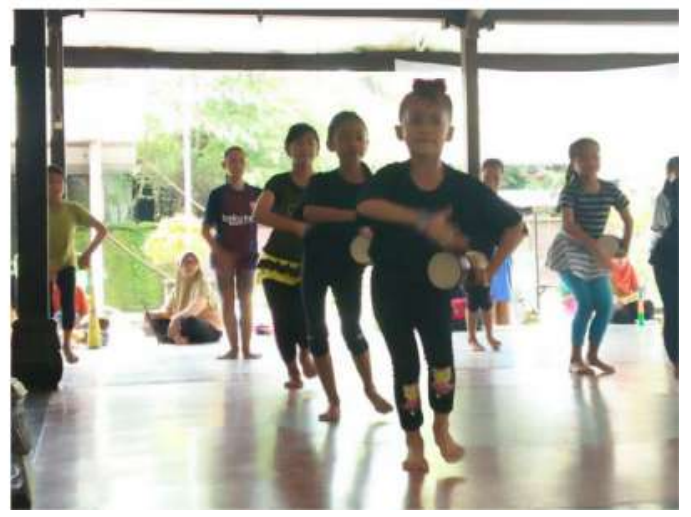

Foto Kegiatan Latihan Reyog Kendang Anakanak di Sanggar Gatra Kencana 